\title{
Six Ways of Looking at Context
}

Alan Maley

\begin{abstract}
This short article is an attempt to specify more clearly what we might mean by the term 'context'. I examine six aspects of context: Physical, ametrial and economic; _Socio-poleitical and religious; I Linguistic; Philosophical and educational; Family and peer group; Psychological, relational and affective. I discuss each of these relating to the classroomteaching and learning of English.

Language learning and the context

Learning involves a 'something' to be learned and a context of circumstances in which it takes place. It is this rich texture of factors, ranging from the material to the ethereal, that I want to reflect on in this article. Clearly these factors intersect and overlap in complex and not always predictable ways, but I shall nonetheless attempt to separate out the following six strands for discussion:
\end{abstract}

$\sim$ Physical, material, economic factors-

$\sim$ Socio-political and religious factors:

$\sim$ Linguistic factors:

$\sim$ Philosophical /educational factors:

$\sim$ Family and peer group factors:

$\sim$ Psychological, relational, affective factors:

\section{Physical, material and economic factors.}

On the face of it, it appears obvious that material circumstances have a massive influence on the effectiveness of learning. In the 1960's I worked with primary schools in Ghana. Many of them, particularly in rural areas, lacked even the most basic facilities: no desks or chairs, few books, blackboards pitted like battlefields...Classes were crowded into classrooms as hot as ovens. Children had sometimes to walk long distances to school after performing early morning chores such as foraging for wood and collecting water.
Many were under-nourished or suffering from malnutrition.

Poverty, disease and malnutrition are the daily reality in many educational settings worldwide, including parts of Nepal and India. They are certainly not confined to West Africa. Neither are they the exclusive reserve of rural communities. However, I want to suggest that such deprived material settings can sometimes - all too rarely but sometimes - be overcome by affective and relational factors. I have seen some of the most joyful and creative educational moments of my career in just these kinds of classrooms: an improvised 
puppet show using old newspapers to make the puppets and a table on its side as a stage, with the kids performing a play they had themselves written; an art exhibition of collages made from the clippings of the seamstresses stalls in the market... I do not suggest for a moment that such deprived environments are in any way desirable, but we should not assume that material circumstances are everything. I have seen some of the most lacklustre, deadening lessons given in classrooms with ergonomic furnishings, designer lighting and with all the technical equipment one could desire. The material circumstances are important but not always decisive.

\section{Socio-political and religious factors.}

These factors can exercise a negative influence on learning when, for example, the belief systems in place exclude (or downgrade the importance) of women in education. There are also cases where certain sections of the population are given privileged access to education to the detriment of other sections, as, for example in Malaysia or India. Or the system may take a non-scientific stance towards science, as in the Creationist approach in the US, or view science as a fixed body of expertise to be used for political objectives rather than as an open-ended practice of inquiry. They clearly affect the way geography or history are taught. Even the Mercator projection, which forms the basis for many maps, has a lot to answer for. Politics can affect language learning too, as in cases of postcolonial resistance to the language of the colonisers, or in views of one's own language as being inherently superior to the one being learned. Factors such as these are more influential and more stubborn than even material factors, partly because those who hold such views are often unaware that they do so.

\section{Linguistic factors.}

The linguistic environment can have significant effects on language learning in particular. Is the society monolingual (the exception), or plurilingual, where it is common for people to switch between several languages, and where they do not regard learning another language as difficult? Is the target language being learned in a country where it is in use outside the classroom, or not? How distant are the mother tongue and the target language, and what effect does this have? (Curiously, languages which are close to one's own are not always the easiest to learn.) What difference does it make if the language being learned is high prestige or low prestige? Because English is the major international language, are native speakers of English disadvantaged in their learning of other languages? How do folk beliefs about language impact on learning? ('French is the language of culture', 'Italian is so musical', 'German sounds harsh', 'Greek sounds really masculine.' etc.). And how do attitudes toward the target language affect the learning of it? Do I resent having to learn this language, or do I embrace the opportunity? Are my most cherished values put at risk when I acquire this language?

\section{Philosophical and educational factors.}

Some societies accord greater prestige to education than others and this clearly affects the educational environment. Of course, it may also have a negative impact on some members of the society, who may be excluded or who simply drop out of a race they feel certain they can never win. There are also clear differences between broadly elitist systems and 'democratic' ones. Sadly, it is often the case that equality of access to education may not guarantee equal quality of provision however. But there are winners and losers in all societies, 
and to teach or learn in an environment of 'losers' is all too often a guarantee of failure, leading to more failure in a downward and irreversible spiral.

Other factors include the overall beliefs about how learning should be conducted. Broadly conservative or traditional beliefs place a high value on discipline, effort, competition, memorisation and testing, and tend to view learning as something difficult and painful. By contrast, more liberal or exploratory approaches view learning as a pleasurable, creative and cooperative enterprise where the emphasis is on the quality of the process rather than the shortterm product in the form of examination results. I am aware of the dangers of stereotypes, of course, but it is nonetheless true that generalisations can sometimes usefully be made. There are societies where the form is more important than the substance, the word more important than the deed. It is important however to avoid attributing such beliefs to whole societies, ("the Chinese are all influenced by Confucian values", etc.). There is often more variation within societies than between them. Things change, and one complaint increasingly heard about young 'nouveau riche' Chinese students abroad is precisely that they do not conform to the expected disciplined and obedient model!

\section{Family and peer group factors.}

The family, and in particular parental influence, is still paramount in the environment of most learners. Parents can exert positive influence through active involvement in their children's education, by non-coercive encouragement, by supporting them in moments of crisis and through their example as role-models. This is perhaps nowhere so apparent as in the development of literacy. Those children whose parents read to them at bedtime, who provide reading material of compelling interest to their kids, who show themselves to be avid readers themselves - those children become readers, and reading is the best predictor of academic success that we have. Children whose parents are not like that will have a struggle ahead to achieve even minimal standards of literacy. Most people learn more from their parents - for better or worse - than they ever do from their teachers.

Arguably, they also learn far more from their peers, both positively and negatively. The pressure to conform to group norms has never been stronger, supported as it is by an aggressively consumerist ethos and by the social media. How they look, what they own, how they speak, how quickly they can adjust to the latest change of fashion - all are subject to the unforgiving judgements of their peers. But they also learn how to be with other people, to respect and be respected by them, to give and receive understanding... and much else. We sometimes forget just how much kids learn outside school: arguably more than they ever learn inside it. And this too is part of the wider learning environment, especially when so much information is so readily available on the Internet.

\section{Psychological, relational, affective factors.}

An article of this length can scarcely do justice to the multitude of personal factors which pervade the learning environment. All I can do is remind myself, and you, of some of the stronger currents running beneath the surface of the learningteaching surface. Hormones, hangovers and hyper-activity can cause havoc in any learning group. The moods, expectations, aspirations and attitudes of both teachers and learners also form an important part of the learning environment. Just how the skilful teacher manages to harness and orchestrate the energies and tensions of a group, and direct them in productive directions remains one of the greatest 
pedagogical mysteries. As teachers, we have all experienced classes which went like a dream, and those which felt like endless nightmares. How to achieve the 'flow' experiences of the former, where both teacher and class are lost in the 'effortless effort' of the moment is elusive, though Jill Hadfield's book, Classroom Dynamics gives valuable signposts. Nancie Atwell, in The Reading Zone, also gives some guidance in how to harness the energy of a group in the shared and powerful experience of reading. And the 'flow' bible is, I guess, still The Inner Game of Tennis by Timothy Gallwey. As teachers we need to be 'present' in the fullest sense, yet simultaneously absent, so that we leave space for the individuals and the group to enact their learning. I have a particular conviction that it is the teacher's voice quality which is a key to this, though I have only anecdotal evidence to support my case (Maley, 2000). But is certain that teachers' voices remain with us for good or ill throughout our lives. The immediate chemistry of a class, requiring split-second decisions by the teacher is unlikely ever to be completely anatomised, yet it is this which ultimately overrides virtually every other factor I have discussed.(Underhill and \& Maley, 2012) Good luck!

\section{References}

Atwell, N. (2007) The Reading zZone. New York: Scholastic.

Gallwey, T. (1974) The Inner Game of Tennis. London: Pan Books.

Hadfield, J. (1992) Classroom Dynamics. Oxford: OxfordUniversity Press.

Maley, A. (2000) The Language Teacher's Voice. Oxford: Macmillan/ Heinemann

Underhill, A. and Maley. A. (2012) Expect the unexpected. English Teaching Professional, Issue 82, Sept. 2012 .

\section{Author's bio}

Alan Maley's career in ELT began with The British Council in 1962. Since retiring from Assumption in 2004, he has occupied many visiting professorial posts at many Institutions. He was a founder member of the Extensive Reading Foundation, and cofounder of The C Group. He is a pastPresident of IATEFL, and was given the ELTons Lifetime Achievement Award in 2012. 